\title{
Self-Regulatory Policy of Accounting and Auditing Profession and Its Effect on Audit Expectation Gap in Nigeria
}

\author{
Paul N. Onulaka \\ Department of Accounting, Faculty of Business and Law \\ Leeds Beckett University Leeds, United Kingdom. \\ E-mail: p.onulaka2534@ student.leedsbeckett.ac.uk
}

DOI: 10.5296/ijafr.v5i2.8220

URL: http://dx.doi.org/10.5296/ ijafr.v5i2.8220

\begin{abstract}
From the very beginning, auditing is pretty much a self-regulated profession and has some ethical rules of thumb to follow in practice. But the plethora of corporate failures and scandals in recent past where auditors' instrumental role is evident in many instances raise question about the validity and suitability of "self-regulation" in auditing, especially in Nigeria and some other parts of the world where auditors need to perform auditing in ever complex risk management process. However, to restore the public confidences within and outside the auditing profession and to raise the overall audit quality, many countries are establishing some super regulatory bodies to set accounting and auditing standards and regulate the activities of auditors with a view to reducing audit expectation gap. The reason for this paradigm shift is because events over the last decades has shown that an inverse relationship appears to be existing between efforts being made to reduce audit expectations gap by accounting and auditing profession and the actual number of audit failures. This study adopted a cross sectional survey design. This was designed to investigate whether there is a relationship between the self-regulation of accounting and auditing profession in Nigeria and audit expectation gap. Pearson Product Moment Correlation Coefficient was used for data analysis. The finding shows a strong relationship between self-regulation and audit expectation gap and the deficient standard gap is not only associated with self-regulation but other legal pronouncements which the respondents considered obsolete and need to be revamped.
\end{abstract}

Keywords: Self-regulation, Auditing Profession, Expectation gap, Corporate Scandal 


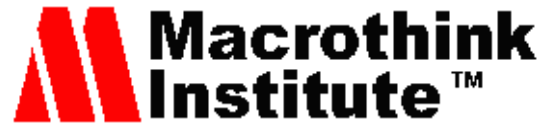

International Journal of Accounting and Financial Reporting

ISSN 2162-3082

2015, Vol. 5, No. 2

\section{Introduction}

External auditors throughout the English-speaking world are facing widespread criticism and extensive litigation. According to extant literature it is postulated that this is a manifestation of the audit expectation-performance gap, the gap between society's expectations of auditors and auditors' performance. This gap is conceived to comprise two major constituent parts, the reasonableness gap and the performance gap, with the latter subdivided into deficient standards and deficient performance components (Porter 2005). On the other hand self-regulation policy of the accounting and auditing profession has been claimed to be instrumental to standard setting on what audit objectives should be (Humphrey 1997). The Audit Expectation Gap has become a very important issue within the financial reporting arena because the wider the gap the less credibility and loss of public confidence in audit process (Akinbuli 2010).

According to Committee on Basic Auditing Concepts of the American Accounting Association (AAA, 1973), auditing has been defined as 'a systematic process of objectively obtaining and evaluating evidence regarding assertions about economic actions and events to ascertain the degree of correspondence between those assertions and established criteria and communicate the results to interested users. An audit function becomes important in the contemporary business environment because of a paradigm shift in the structure of business corporations over the last four centuries, from small entities to huge multinational companies (Lee, Ali and Gloeck, 2009). As companies have grown in size, their management has passed from shareholder-owners to small groups of professional managers entrusted to execute the wealth creation function. As a result of this separation of ownership interests from management functions, auditors have come to "occupy primary importance in bridging the communication gap between management of enterprises and their shareholders through their authentication of the reliability and correctness of financial reporting (Swamy 2007:1). Although the existence of audit expectation gap and its associated problems has been acknowledged for several decades now, it appears that Liggio (1974) was the first to apply the term "audit expectation gap" in the auditing literature (Lee et al, 2009). Liggio (1974) defined audit expectation gap as "the difference between the level of expected performance as envisioned by the user of a financial statement and by the independent accountant'. To be self-regulating means to be trusted with the authority of the state, i.e. with the authority to administer binding law (Lahey, 2007). The rationale for this trust is always the idea that the interests of the public are served by self-regulation. (Lahey, 2007).

\subsection{Statement of the Research Problem}

In a study on 'Eliminating the Audit Expectations Gap: Reality or Myth' by Ojo (2006) it was noted that events over the last decades has shown that an inverse relationship appears to be existing between efforts being made to reduce audit expectations gap by accounting and auditing profession and the actual number of audit failures in Nigeria.

For example, Olowokere (2010) claimed that the refusal of auditors to assume responsibility for fraud detection and reporting exercise; and their involvement with non-audit services and self-regulation policy appear to have extended the audit expectations gap. It is for this and 


\section{Mll Macrothink}

International Journal of Accounting and Financial Reporting

ISSN 2162-3082

2015, Vol. 5, No. 2

other reasons that this research is being designed to achieve the research objectives in section 1.5 and to provide answers to the research questions outlined in section 1.5.1 of this study.

According to Millichamp, as cited in Akinbuli (2010), Auditing as a discipline evolved because of the practice of stewardship accounting and from then onward property owners appointed individuals to manage their resources for a period after which the stewards present an accountability report. For this reason, Salehi (2007), cited by Lee , Ali and Gloeck,( 2009) opined that "the auditor plays a centrifugal as well as centripetal role today". This, according to Salehi, (2007), 'facilitates good corporate governance, accountability and transparency among corporate participant, and more importantly, it has become the gatekeeper of financial truth'. Similarly, Alleyne and Howard, (2005) claimed that notwithstanding the importance of the audit function in the current capitalist economy the duties and responsibilities of auditors have never been well defined. To date, the duties and responsibilities of auditors have remained the most controversial issue in auditing (Lee et al, 2009). Humphrey, (1997) opined that the role of auditors in society has always been surrounded by "mystique or paradox" (ie a situation that seems strange because it involves two ideas or quantities that are very different) and Power (1994), regards this as the crisis in the present-day auditing. A review of auditing literature shows how the auditing profession has responded to this problematic issue by coining the phrase "audit expectation gap" and weak participation in the debate by accounting profession fuelled by major financial scandals, such as the US Savings and Loan debacle, Enron and WorldCom, US accounting firms lost suit after suit which involve billions of dollars. In Nigeria for example, financial scandals involving the senior management and Directors of banks like Oceanic Bank plc, Intercontinental Bank plc, BankPHB and many others contributed to public loss of confidence in auditing process in Nigeria. This credibility, monetary and reputation losses, increased legal fees, costly out-of-court settlements, (in case of Nigeria), skyrocketing insurance premiums, threatened regulation are some of the costs associated with audit expectation gap' (Wolf, Tackett and Claypool, 1999:472;, Akinbuli, 2010:42) . According to Humphrey (1997), the above failures have regularly put the audit function under public microscope.

Audit or assurance is concerned with the way an organisation's performance has been reported. It ensures the balanced, complete and accurate portrayal of all outcomes that may affect stakeholders in those areas that the stakeholders themselves believe to be critical (Adams and Evans, 2004). Stakeholders should be able to rely on the information in audited reports in making their decisions about investments, products and services, employment, where to live and other issues that may affect them directly. Managers should have an understanding of the wider impact of their decisions and policies (Adams, 2002).

As stated earlier, some sources of academic literature such as Rodda (2001) assume that the meaning of an audit is objective or fixed. Whist others such as Lee et al (2009) see it as not 'objective' or 'fixed'. In other words, audit is recognized as a social phenomenon which constantly changes depending on the interaction between the audit profession and the public. (Power,1998; Sikka et al, 1998). Many have recognized the changes in the audit function as an effort by the auditing profession to ensure that the profession remains relevant to its 
constantly changing environment. Flint (1988), Power (1994; 2000), Epstein and Geiger (1994) share the same view as they are of the opinion that the progression in the practice of auditing was basically in response to a perceived need of the public who seek information or reassurance about their conduct or performance of their business which they placed on the stewardship of the management.

The Enron scandal in 2002, however, prompted a global shift to re-regulation (Kinney, 2005). In the US, the Sarbanes Oxley Act (SOX) (2002) introduced major changes to the US audit, financial and corporate governance regimes and similar regulatory changes subsequently occurred in the UK and many other countries (Lennox, 2009). Scandal and regulatory changes has brought attendant changes in the conceptualisation of practice. For example, Gold, Gronewold, and Pott (2012) present evidence that the dominant audit discourse has shifted from one of the 'business value' to one of 'audit quality'. Quality external auditing is integral to the effective functioning of our capital markets. It is an essential service requiring specialist skills and knowledge. Therefore, the sustained viability of the audit profession is critical and in particular attracting, retaining and developing the right people for the profession (ICAA, 2012). Sharing a similar view, Holmes and Brun (2009) observed that the avalanche of regulations by the profession has not prevented the meltdown in the banking sector which the developed and developing economies have recently experienced. Some observers have questioned whether audit quality failures contributed to the crisis (Holmes and Brun 2009). According to Treasury Committee, (2009) that is, the UK Parliament Treasury Committee as part of its inquiry into the Banking Crisis, investigated the role of auditors and concluded that they:

"had received very little evidence that auditors failed to fulfill their duties as currently stipulated. The fact that some banks failed soon after receiving unqualified audits does not necessarily mean that these audits were deficient. But the fact that the audit process failed to highlight developing problems in the banking sector does cause us to question exactly how useful audit currently is. We are perturbed that the process results in 'tunnel vision', where the big picture that shareholders want to see is lost in a sea of detail and regulatory disclosure" (Paragraph 221).

There are several attempts to account for why there is audit expectation gap among researchers in the auditing profession. Humphrey et al. (1993), McEnroe and Martens (2001), argue that the gap exists due to misinterpretation and misunderstanding of the meaning of auditing by the users. The above studies suggest that the users do not understand the audit functions and the role of auditors. Consequently, they have unrealistic expectations of auditors. Earlier, research by the Canadian Institute of Chartered Accountants (CICA, 1988) and Porter (1993) established the deficient performance, deficient standards and unreasonable expectations as the components of the audit expectation gap. However, a recent empirical study conducted by Porter and Gowthorpe (2004) has shown that these components have changed over time although the perceptions of pessimism as to the audit function have not been eliminated.

The audit expectations gap centers on several issues, most notable among them are; the auditor's roles and responsibilities as opined by Porter,(1993); Fazdly and Ahmad, (2004); 
and Dixon et al, (2006); the nature and meaning of audit report massages as opined by Monroe and Woodliff, (1994); and Gay et al, (1998); auditor's independence as opined by Sweeney, (1997); Lin and Chen, (2004); Alleyne e al, (2005). Furthermore, Humphrey (1997) classified the issue on the audit expectations gap into four main areas: audit assurance, audit reporting, audit independence and audit regulation.

\subsection{Significance of the Study and Contribution to Knowledge}

The perception of Nigeria as a risky country for the flow of Foreign Direct Investments can, in part, be attributable to the limited financial reporting disclosures made by reporting entities in Nigeria. This in no small measure contributed to audit expectation gap which made it imperative to undertake this study.

Audit Expectations Gap is a growing area in accounting and financial reporting that is attracting a lot of interest worldwide. However, most of the studies that have been carried out in this area, especially in Nigeria have centered on AEG between the users of financial statements in general and auditors. There are no studies yet in Nigeria, ( as far as extant literature reveals) known to this researcher, which addresses this aspect of self regulation policy of auditing profession and its effect on AEG. This study will close the research gap in this area and the results would also be especially important to the Financial Reporting Council of Nigeria who, in a recent strategic initiative paper (ICAN, 2014)) states that it actively seeks the input of users and practitioners and researchers in the development and clarification of auditing standards in an effort to render them meaningful to both users and audit practitioners.

\subsection{Objective of the Study}

The main objective of this study is:

- To find out the extent to which self-regulation policy of auditing and accounting profession in Nigeria affect Audit Expectation Gap (AEG).

- To find out the effect of establishment of the Financial Reporting Council of Nigeria (FRC) on AEG.

- To find out if self-regulation of auditing and accounting profession contribute to deficient standard gap.

\subsubsection{Research Questions}

1' To what extent do self-regulation of auditing profession affect audit expectation gap in Nigeria?

2. Do the self-regulation policy of the auditing profession in Nigeria contribute to deficient standard that is not meeting the expectations of users of financial statements?

3. What effect does the establishment of Financial Reporting Council of Nigeria has on audit expectation gap in Nigeria? 


\subsection{Research Hypotheses}

Ho1: There is no significant relationship between audit expectation gap and the accounting and auditing professions' self-regulation policy.

Ho2: There is no significant relationship on self-regulation and deficient auditing standard in Nigeria.

Ho3: There is no significant relationship on establishment of independent oversight board (e.g. Financial Reporting Council of Nigeria) and audit expectation gap in Nigeria.

\section{Literature Review}

\subsection{Introduction}

In societies within and outside Nigeria, some works have been done on audit expectation gap and self-regulation of accounting and auditing profession Various techniques has been used to boost the quality of financial reporting as a way to reducing audit expectation gap. A review of some of these past works will no doubt provide a direction and framework for this investigation. The knowledge reviewed in this section will be used to test the research hypotheses in 1.6 above.

\subsection{Self-regulatory Policy of Accounting and Auditing Profession}

Islam (2013) observed that from the very beginning, auditing is pretty much a self regulated profession and has some ethical rules of thumb to follow in practice. He further claimed that the plethora of recent corporate failures and scandals where auditors' instrumental role is evident in many instances raise question about the validity and suitability of "self-regulation" in auditing, especially in the 21 st century where auditors need to perform auditing in ever complex risk management process Based on the above the former chairman of US Securities and Exchange Commission (SEC) Arthur Levitt in a paper he presented in 2003 said that "self-regulation by the auditing and accounting profession is a bad joke." Knapp (2011) contended that in June 2001, Enron's chief executive officer (CEO) was ranked as "the No. 1 CEO in the entire country" (i.e. USA) the company became "America's most innovative company" and its chief financial officer (CFO) received the excellence award for innovative capital structure. Yet, just after five months that is, in December 2001, this same company filed for bankruptcy, and it was found that its auditor Arthur Andersen played an influential role in fabricating its financial statements This ignominy is not only for the United States of America (USA), Enron, and its auditor Arthur Andersen, but also for all the auditing and accounting professionals and academicians throughout the world (Islam, 2013). Moreover, there are many evidences where non-audit fees contribute a major portion of total audit revenues of accountancy firm. Consequently, auditors' independence is being compromised. To restore the market confidences within auditing profession and to raise the overall audit quality, countries across the USA, the United Kingdom (UK), Europe, and Asia-Pacific are establishing super regulatory bodies to oversee the functions of auditing and auditors (Islam, 2013). The reason is the higher risks it poses of "regulatory capture", where regulators identify and advance the interests of the regulated over the interests of those who were intended to be protected by regulation (Lahey, 2007). Accountants and other 


\section{Ml Macrothink}

International Journal of Accounting and Financial Reporting ISSN 2162-3082 2015, Vol. 5, No. 2

self-regulating professions are trusted with exceptional self-regulatory authority precisely because their professional commitment to the public good is thought to counterbalance the inherent vulnerability of self-regulation to regulatory capture.

Witten (1990) and Mitchell (1990), asserted that auditing profession's controlling bodies are frequently accused of the fact that the process by which the self-regulation is applied is not carried out openly but behind close door. This according to them has led to an appeal being made to the auditing profession for greater accountability and on the basis of this the importance of user perception is anchored. It is on this basis that Anderson, Maletta \& Wright, (1998) argued "the effectiveness of our self-regulation is not measured solely by how well we do the job, or by how many poor or illegal performers are weeded out; it is also judged according to how well the public thinks the self-regulation process is carried out. The question we must then ask ourselves, of course, is can we maintain the public perception of effective self-regulation while simultaneously maintaining the secrecy of our disciplinary actions?"

"Professions disciplinary procedures are even more feudal. Occasionally, in secret meetings, from which its own membership, press and public are extended, it suspends some individuals from membership.... and what about the big fish? According to Lee, Ali and Gloeck (2009), to date, no partner from any major firm has ever been criticised by any of the organs within the regulatory authority, again and again The Institute of Chartered Accountants is completely dominated by the interest of major firms and their financial might".

Sikka et al (1992) cited in Salehi 2006: $72-73$ and 1998:301 asserted that the reason for an audit expectation gap are two-fold. Firstly, it is due to the contradiction between minimal government regulation of the profession, and the profession's right to self-regulation, particularly, the problem of the profession's overprotection of self-interest. Secondly, it has resulted from the clash between auditors and the public over the preferred meanings about the nature, practice and/or outcome of auditing. This perception is shared by Witten (1990:8). He argued that the disciplinary process has to be more open in a profession based on self-regulation. "Washing hands quietly in the back yard doesn't cut it anymore". (Witten 1990).

Salehi (2007) sharing similar view said that the accountancy bodies are of the opinion that the public ought to have greater confidence in their activities. He summed up the above feelings by asking: "Is the 'trust me' approach to self-regulation good enough at a time when the public's attitude towards corporate and professional ethics is 'show me'? The old secretive ways of dealing with the profession's internal problems lag behind the public's expectations and gloss over problems such as potential conflicts of interest that could affect the public directly". Brady (1992) asserted that the merging of large auditing firms has resulted in the professional bodies being accused of no longer being fully representative. He further claimed that the Institute of Chartered Accountants in England and Wales is dominated by the senior partners of the Big four so that it is becoming less significant. For example, the research study on market participants in 2006 by EU study group, it was found that research participants expressed concern about audit market concentration. This is because, in United Kingdom the remaining Big four firms after the demise of Arthur Andersen in 2002, 
PricewaterhouseCoopers, Deloitte, KPMG and Ernst and Young have a 97\% market share of auditing (Financial Times Stock Exchange (FTSE-350) Companies.). A number of initiatives have been established to address this issue of public concern in UK but little or no progress has been made (Cosserat and Rodda 2009) The question now is with the existence of such Cartel how can new players have the opportunity to enter into the market?

This same view was expressed in a similar study by Humphrey et al, (1992) and Lee \& Azham (2008) who claimed that the self-regulatory monopoly granted to the accounting and auditing profession has been questioned with regard to which extent it operates in the public interest. They further opined that personal interest of the audit profession (e.g. economic interests) may compromise the audit quality at the expense of the public/client thereby increasing the expectation performance gap. This observation is in tandem with the findings in Cosserat and Rodda (2004) which asserted that the general view of the legal profession is that the verdict in Caparo case of 1990 by the House of Lords implied that it is up to the UK Parliament to introduce legislation whereby auditors' statutory responsibilities could be extended to meet the interest of the investors.

Ihendinihu and Robert (2014) examined the perception of students and the influence of audit education as a veritable tool for curing ignorance arising from poor knowledge of the auditing process said that widening the scope of the audit through regulatory process may accommodate greater reasonable expectations of users.

Sikka et. al., (1992) cited in Salehi, Mansoury and Azary (2009), argued that independence is the main cause to reduce the expectation gap. He stated "as a first step towards reducing the expectation gap, is auditing standards and hence audit objectives should be shaped by open, democratic, accountable bodies, independent of the accountancy profession and the Department of Trade and Industries (DTI).

\subsection{Deficient Standard Gap and Self-regulation}

Standard is defined according to Merriam Webster Dictionary as a level of quality, achievement etc. that is considered acceptable or desirable. In line with the above definition, Generally Accepted Auditing Standards (GAAS) are sets of standards against which the quality of audits are performed and may be judged (AICPA). In United States of America the standards are promulgated by the Auditing Standard Board, a division of the American Institute of Certified Public Accountants (AICPA).

Similarly in United Kingdom, In July 2012, as part of a reform of the Financial Reporting Council (FRC), the Auditing Practices Board (APB) was replaced by the Audit \& Assurance Council. Responsibility for setting auditing standards was assumed by the FRC Board, with the Audit and Assurance Council acting in an advisory role to the FRC Board and its Codes and Standards Committee (Knowledge guide to UK auditing Standards, ICAEW).

According to the Preface (p.iv) of the Nigerian Standards on Auditing (NSAs, 2013), The Institute of Chartered Accountants of Nigeria (ICAN) is established by Act of parliament No.15 of 1965 to set standards and regulate the practice of auditing and accountancy in Nigeria. In Nigeria, the Financial Reporting Council (FRC) was established by Act No.22 of 2003. According to section 11 (a) of the Act, one of the main objective of the council is 


\section{Mll Macrothink}

International Journal of Accounting and Financial Reporting ISSN 2162-3082 2015, Vol. 5, No. 2

to protect the investors and other stakeholder's interest. Section 26 (a) said that the Council will develop or liaise with relevant professional bodies on auditing and ethical standards set by it and promote auditing standards which set out the basic principles and essential procedures which external auditors in Nigeria are required to comply. Among the functions of FRC according to section 8 (1) (q) is to develop or adopt and keep up to date auditing standards issued by relevant professional bodies and ensure consistency between the standards and the pronouncements of the International Auditing and Assurance Standard Board (IAASB). The Institute of Chartered Accountants of Nigeria (ICAN) in April 2013 issued the Nigerian Standards on Auditing (NSAs) to be effective for audits of financial statements for periods beginning on or after April 2 2013. Based on the forgoing, it can be deduced that FRC of Nigeria do not issue auditing standards rather it adopt in its entirety the standards issued by ICAN for their members to ensure compliance. But the FRC is established to act as an independent oversight body for external auditors in Nigeria. One of the questions that is yarning for answer in this study is, are the FRC transparently independent of the Institute of Chartered Accountants of Nigeria in setting standards for accountants in Nigeria? The International Auditing and Assurance Standard Board (IAASB) is part of IFAC, which is entirely funded by accountancy professional bodies worldwide and the large audit firms. IFAC is based in New York and appears to be heavily influenced by the US accounting and auditing profession (Gold, Gronewold and Pott 2012).

Among the major causes of audit expectations performance gap identified by Porter and Gowthorpe (2004) was deficient standard gap.

\subsection{Auditors' role on Fraud}

Since the demise of Enron, Parmalat and WorldCom, the issue concerning auditors' responsibility for material fraud is again a cause reducing public confidence in the audit (Cossarat and Rodda 2004). The profession has responded by strengthening auditing standards with regard to fraud. For example ISA 240 was redrafted to clarify the auditors' role in detecting and preventing fraud. In developing the standard, the IAASB has been influenced by the US Public Oversight Board's Panel on Audit Effectiveness' recommendations that auditing and quality control standards be made more specific and definitive. The redrafted ISA 240 expands on the ISA 315 (Redrafted) and ISA 330 (Redrafted) are to be applied in relation to risks of material misstatements due to fraud. The ISA requires that auditors carry out an extensive range of procedures to enhance the prospect of detecting material financial statement fraud. This according to the IAASB Task Force on Rebuilding Public Confidence on Financial Reporting (2003), represents Phase 1 of an International project on fraud and in Phase 11 proposal the auditors are required to perform forensic style procedure in every audit with a view to detecting material misstatement in the financial statement and report same to those charged with governance i.e. the board or audit committee.. But contrary to this pronouncements the Nigerian Standards on Auditing (NSA 2013) states categorically that it is not the responsibility of auditor to detect fraud and material misstatement in financial statement and that prevention and detection of fraud and irregularities rest with management and those charged with governance. Cossarat and Rodda (2009) observed that despite all the IAASB pronouncements currently in place, the issue of 


\section{MInstitute Mach $^{m}$}

International Journal of Accounting and Financial Reporting ISSN 2162-3082

fraud and its potential cause of material misstatement is of ongoing concern. As a result of this problematic issue and subsequent wide consultation the 2008-9 Strategic and Operational Plan issued by IFAC's International Ethics Standards Board for Accountants (IESBA 2008) includes as a key project the development of additional guidance regarding the ethical responsibilities of professional accountants who encounters fraud and illegal acts on cause of their duties. The seemingly confusion in the profession corroborates Olowokere and Ojo's findings in similar studies in Nigeria.

Disenchantment with the quality of auditing standards, as set by the US profession, led to the transfer of the responsibility for standards setting to the Public Companies Accounting Oversight Board (PCAOB) under the Sarbanes-Oxley Act 2002. The impact of these changes on AEG is yet to be made manifest. In 2010, an exploratory study with 30 participants by Ismail, Mustapha and Ali was undertaken in Malaysia and it was found that although the auditing profession in Malaysia has International Auditing Standards as prescribed minimum level of quality in the delivery of audit assurance services, self regulation by the profession alone appears inadequate to ensure delivery of quality audit services (Ismail, Mustapha and Ali, 2010).Their views are similar to the findings in Salehi, Mansoury and Azary (2009)

\subsection{Knowledge Gap and Audit Education}

Among the reasons adduced for AEG within the professional circle is lack of knowledge of audit objective by the users of financial statement.

For example, in Bangladesh, Rehana (2010) asserted that there was a significant expectation gap among students who undergo a course in auditing and those who did not. This same view was consistence with the findings of Pierce and Kilcommins (1996) in Dublin City University. Similarly, Ihendinihu and Robert (2014) made an empirical study on the role of Audit Education in Minimizing Audit Expectation Gap in Nigeria. The study was carried out to determine whether the provision of auditing course as part of a third year business degree curriculum could narrow down the expectation gap. The study adopted a quasi-experimental pre-test post-test non-equivalent control group design, using three randomly selected intact groups of University students. A modified and validated five-point Likert scale questionnaire was administered to each of the three groups. The data was analysed using analysis of covariance (ANCOVA) and Post Hoc Pair-wise Comparison. The result indicate that exposure of students to a course on auditing significantly enhanced the knowledge of students in two experimental groups and accordingly reduces their expectations on the scope, reliability and decision usefulness of audit function. But again, the students at 400 level cannot be true representative of core investors like the fund managers. Teaching the investing public that the objective of an audit is to express opinion on the true and fair view of a company's financial position at a given period may not be enough to convince potential investors to rely on audited financial statements for investment decisions. Having briefly reviewed the some extant literatures on the research topic, the next session will highlight the methodological approach adopted to answer the research questions outlined in section 1.5.1 of this paper. 


\section{MInstitute"mk}

International Journal of Accounting and Financial Reporting

ISSN 2162-3082

2015, Vol. 5, No. 2

\section{Method}

\subsection{Research Design}

The study adopted a cross sectional survey design. This was designed to investigate whether there is a relationship between the self-regulation of accounting and auditing profession in Nigeria and audit expectation gap.

\subsection{Population Sample Size and Sampling Technique}

The population of the study from which the sample was drawn comprised of Auditors in public practice selected from Directory of members from the Institute of Chartered Accountants of Nigeria (ICAN), accountants and auditors not in public practice, Investors and capital market operators (which include Stockbrokers and Financial Analysts representing users of financial statement all of which were selected from the Lagos stock exchange list of operators). Purposive or judgment sampling was adopted to ensure that only knowledgeable respondents were chosen. The rationale for choosing this sampling method is explained by Foroughi (1981) He argued that judgmental sampling is applicable under the following conditions: (i) when the desired elements of the sampled population do not equally and universally exist in all units of the target population; (ii) when inclusion of exceptional and special units within the sampled population is essential for the completeness of the research. Given such justification, a simple random selection would most likely have missed the more important elements and was therefore rejected. This approach was also adopted in Lee, Ali and Gloeck, (2009).

A sample consisting of respondents in Lagos and Abuja was considered a good representation of the respondents groups since the ultimate test of a sample design is how well it represents the characteristics of the population it purports to represent (Denscombe, 2003; Ogunbameru, 2003). Two hundred (200) questionnaires were distributed by mail and partly by hand to members of the Institute of Chartered Accountants of Nigeria (ICAN) during the MCPE in Lagos Airport Hotel the venue of the workshop out of which only 140 were returned but 10 were found to be useless. The respondents were required to indicate the extent of their agreement in the list of semantic differential belief statements on the score of 1 to 5 . A score of one (1) represented strong disagreement with the statement while a score of (5) five represented strong agreements. This type of scaling was in agreement when items are to be judged on a single dimension and arrayed on a scale with equal interval (Alrek and Settle, 1995, Oseni and Ehimi, 2010; Baridam, 2008).

\subsection{Data Collection}

The data collection comprised of both primary and secondary data. The primary data were collected from the responses received from the structured questionnaires while secondary data were collected from Stock Exchange Quarterly Digest and annual report from the Nigerian Stock Exchange (NSE) as well as the search engine from the internet.

\subsubsection{Method of Data Analysis}

Descriptive statistical tools used for this research include tables, percentages and frequency distribution while Pearson Product Moment Correlation Coefficient was used for data 


\section{Macrothink}

International Journal of Accounting and Financial Reporting

ISSN 2162-3082 2015, Vol. 5, No. 2

analysis. This method is appropriate because, according to Braun and Clark (2013) the method is the most widely used method of measuring the degree of relationship between two variables and can only be used when the data is on the interval scale of measurement, that is, when the data consists of actual measurements (Oakshott 2006).

The construct validity which is concerned with whether a data collection measure measures what it aims to measure was taken into account in the construction of the questionnaire which was also confirmed by two senior academic researchers (Braun and Clarke 2013) Pearson's coefficient of correlation can be worked out using the following model:

$\mathrm{r}=\underline{\mathrm{n}(\Sigma \mathrm{xy})-(\Sigma \mathrm{x})(\Sigma \mathrm{y})}$

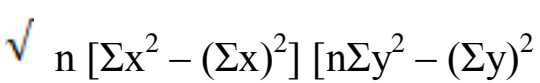

Where

$\mathrm{r}=$ correlation coefficient

$\mathrm{X}=$ independent variables

$\mathrm{Y}=$ dependent variables

$\mathrm{N}=$ the numbers of observations of $\mathrm{X}$

Kuder-Richardson (K-R) Formula 21 was used to test the reliability of all the items in the observations by applying the formula as stated below, and the coefficient of reliability was 0.81 as indicated below. The coefficient of reliability of 0.81 shows a high level of reliability using Kuder-Richardson formula.

$\mathrm{R}_{\mathrm{k}-\mathrm{R}} 21=1-\quad \underline{\mathrm{x}(\mathrm{n}-\underline{\lambda})}$

$$
\mathrm{ns}^{2}
$$

where: $\mathrm{R}_{\mathrm{k}}-\mathrm{R} 21=$ Kuder-Richardson reliability coefficient

$\mathrm{n} \quad=$ number of items in the test

$\lambda \quad=$ mean score on the test

$S^{2}=$ test variance (measure of variability) 


\section{Macrothink \\ International Journal of Accounting and Financial Reporting \\ ISSN 2162-3082 \\ 2015, Vol. 5, No. 2}

\section{Data Analysis and Interpretation of Results}

Hypothesis 1: There is no significant relationship between audit expectation gap and the accounting and auditing professions' self-regulation policy.

Table 1: Response on key Issues relating to the relationship between AEG and the self-regulatory policy of the Auditing profession in Nigeria

S/N Respondents Groups

\section{STATEMENTS}

1 Accounting and Auditing profession's

self-regulation policy

affects Audit Expectation

Gap (AEG) in Nigeria

2

Self-regulation of

Auditing Profession result

to deficient standards

settings.

3

The establishment of

Independent Oversight

Board will have no effect

on AEG in Nigeria

4 Auditors' responsibilities

will be properly defined if

independent oversight

body is in place

5 With the self-regulation policy of auditing

profession auditors'

independence will not be

transparent.

Source: Field Survey 2015
Auditors and Regulators

Respondents ( Group 1)

$\begin{array}{llllllllll}\mathrm{SA} & \mathrm{A} & \mathrm{N} & \mathrm{D} & \mathrm{SD} & \mathrm{SA} & \mathrm{A} & \mathrm{N} & \mathrm{D} & \mathrm{SD}\end{array}$

$\begin{array}{llllllllll}25 \% & 16 \% & 6 \% & 40 \% & 13 \% & 58 \% & 22 \% & 4 \% & 12 \% & 4 \%\end{array}$

$\begin{array}{llllllllll}18 & 11 & 4 & 28 & 9 & 35 & 13 & 2 & 7 & 3\end{array}$

$\begin{array}{llllllllll}20 \% & 22 \% & 6 \% & 27 \% & 25 \% & 60 \% & 21 \% & 2 \% & 7 \% & 10 \% \\ 14 & 15 & 4 & 19 & 18 & 36 & 13 & 1 & 4 & 6\end{array}$

$\begin{array}{llllllllll}16 \% & 24 \% & 3 \% & 20 \% & 37 \% & 70 \% & 20 \% & 2 \% & 4 \% & 4 \%\end{array}$

$\begin{array}{llllllllll}11 & 17 & 2 & 14 & 26 & 42 & 12 & 1 & 3 & 2\end{array}$

$\begin{array}{llllllllll}12 \% & 20 \% & 4 \% & 42 \% & 22 \% & 66 \% & 27 \% & 2 \% & 3 \% & 2 \%\end{array}$

$\begin{array}{llllllllll}8 & 14 & 3 & 29 & 16 & 40 & 16 & 1 & 2 & 1\end{array}$ 


\section{Macrothink \\ International Journal of Accounting and Financial Reporting ISSN 2162-3082 2015, Vol. 5, No. 2}

Table1. 2: Calculation of Correlation on key issues raised in Questionnaires administered.

STATEMENT 1: Accounting and Auditing profession's self-regulation policy affects Audit Expectation Gap (AEG) in Nigeria
Auditors and the Regulators
Users of Financial Statements

Options

Points Responses $\mathrm{Xy} \quad \mathrm{X}^{2} \quad \mathrm{Y}^{2} \quad$ Points Responses $\mathrm{Xy} \quad \mathrm{X}^{2} \quad \mathrm{Y}^{2}$
(x)
(y)
$(\mathrm{x})$
(y)

$\begin{array}{lllllllllll}\text { SA } & 5 & 18 & 90 & 25 & 324 & 5 & 35 & 175 & 25 & 1225 \\ \mathrm{~A} & 4 & 11 & 44 & 16 & 121 & 4 & 13 & 52 & 16 & 169 \\ \mathrm{~N} & 3 & 4 & 12 & 9 & 16 & 3 & 2 & 6 & 9 & 4 \\ \mathrm{D} & 2 & 28 & 56 & 4 & 784 & 2 & 7 & 14 & 4 & 49 \\ \mathrm{SD} & 1 & 9 & 9 & 1 & 81 & 1 & 3 & 3 & 1 & 9 \\ \sum & 15 & 70 & 211 & 55 & 1326 & 15 & 60 & 250 & 55 & 1456\end{array}$

Source: Author's Computation (2015)

Table 1.3 Computation of Correlation Table from Statement 1 of the questionnaire

$\begin{array}{cccccc}\text { Options } & \begin{array}{c}(\mathrm{X}) \\ \text { Points }\end{array} & \begin{array}{c}\text { mean }(\mathrm{Y}) \\ \text { Responses }\end{array} & \mathrm{XY} & \mathrm{X}^{2} & \mathrm{Y}^{2} \\ \text { SA } & 5 & 26.5 & 132.5 & 25 & 702.25 \\ \text { A } & 4 & 12 & 48 & 16 & 144 \\ \text { N } & 3 & 3 & 9 & 9 & 9 \\ \text { D } & 2 & 17.5 & 35 & 4 & 306.25 \\ \text { SD } & 1 & 6 & 6 & 1 & 36 \\ \text { S } & 15 & 65 & 230.5 & 55 & 1197.5\end{array}$

Source: Author's Computation (2015) 


\section{Macrothink}

International Journal of Accounting and Financial Reporting

ISSN 2162-3082 2015, Vol. 5, No. 2

Pearson's coefficient of correlation ( $\mathrm{r}$ ) can be worked out using the following model and results from field survey:

$\mathrm{r}=\underline{\mathrm{n}(\Sigma \mathrm{xy})-\left(\sum \mathrm{x}\right)\left(\sum \mathrm{y}\right)}$

$\sqrt{n}_{\mathrm{n}\left[\Sigma \mathrm{x}^{2}-(\Sigma \mathrm{x})^{2}\right]\left[\mathrm{n} \Sigma \mathrm{y}^{2}-(\Sigma \mathrm{y})^{2}\right.}$

Where $\mathrm{n}=5 \sum \mathrm{x}=15 ; \sum \mathrm{y}=65 ; \sum \mathrm{xy}=230.5 ; \sum \mathrm{x}^{2}=55 ; \sum \mathrm{y}^{2}=1197.5 ; \sum(\mathrm{y})^{2}=4225$

$r=\underline{5(230.5)-(15)(65)}$

$\sqrt{5\left[(55)-(15)^{2}\right]\left[5(1197.5)-(65)^{2]}\right.}$

$=\underline{1152.2-975}$

$\sqrt{(50)(1762.5)}$

$=\underline{177.5}$

$\sqrt{88125}=0.5979$ or $60 \%$

$\mathrm{r}=0.60$

Decision: The $r$ calculated of $+\mathbf{0 . 6 0}$ indicates a fairly positive relationship between the profession's self-regulatory policy and audit expectation gap in Nigeria. We therefore reject the Ho; and accept the alternate hypothesis.

Hypothesis 2:: There is no significant relationship on self-regulation and deficient auditing standard in Nigeria. 


\section{Macrothink \\ International Journal of Accounting and Financial Reporting \\ ISSN 2162-3082 \\ 2015, Vol. 5, No. 2}

Table 2 Responses to key issues raised in the administered questionnaire

S/N Respondent Groups

Statements

Responses

6 Self-regulation policy of accounting and auditing profession is not in the public interest.

7 One of the reasons for

$\mathrm{AEG}$ is due to Auditors and Regulators Respondents(Group 1)

$\begin{array}{llllll}\mathrm{SA} & \mathrm{A} & \mathrm{N} & \mathrm{D} & \mathrm{SD} & \mathrm{SA}\end{array}$

Users of Financial Statements

Respondents (Group 2)

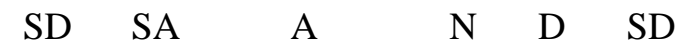
$\begin{array}{llllllllll}4 \% & 6 \% & 3 \% & 20 \% & 67 \% & 70 \% & 18 \% & 2 \% & 7 \% & 3 \%\end{array}$

$\begin{array}{llllll}3 & 4 & 2 & 14 & 47 & 42\end{array}$

contradiction between

minimal government

regulation and the

problem of

overprotection of

self-interest.

8 One of the reasons for

AEG is due to

$$
\begin{array}{llllll}
12 \% & 16 \% & 7 \% & 15 \% & 50 \% & 67 \%
\end{array}
$$

contradiction between minimal government 8

regulation and the

problem of

overprotection of

self-interest.

9 Self-regulatory

monopoly granted to $4 \% \quad 5 \%$

accounting and

auditing profession

$\begin{array}{lll}3 & 4 & 1\end{array}$

15

$47 \quad 42$

10

$\begin{array}{lll}2 & 3 & 3\end{array}$

impaired transparency.

10 Self-regulation reduces

auditors'

$\begin{array}{llllll}20 \% & 12 \% & 6 \% & 30 \% & 32 \% & 66 \%\end{array}$

$26 \%$

$8 \% \quad 0$

responsibilities to

detect and prevent

$14 \quad 8 \quad 4$

$\begin{array}{lll}21 & 23 \quad 40\end{array}$

15

500
fraud.

Source: Author's field survey results (2015) 
Table 2.1: Calculation of Correlation

Question 6 of questionnaire administered: Self-regulation policy of accounting and auditing profession is not in the public interest.

Options Auditors Group

Users Group

Points Responses

Points Responses
$(\mathrm{x})$
(y)
Xy $\quad X^{2} \quad Y^{2}$
$(\mathrm{x})$
xy $\quad X^{2} \quad Y^{2}$

(y)

$\begin{array}{lllllllllll}\text { SA } & 5 & 3 & 15 & 25 & 9 & 5 & 42 & 210 & 25 & 1764 \\ \mathrm{~A} & 4 & 4 & 16 & 16 & 16 & 4 & 11 & 44 & 16 & 121 \\ \mathrm{~N} & 3 & 2 & 6 & 9 & 4 & 3 & 1 & 3 & 9 & 1 \\ \mathrm{D} & 2 & 14 & 27 & 4 & 196 & 2 & 4 & 6 & 4 & 16 \\ \mathrm{SD} & 1 & 47 & 47 & 1 & 2209 & 1 & 2 & 2 & 1 & 4 \\ \sum & 15 & 70 & 111 & 55 & 2434 & 15 & 60 & 265 & 55 & 1906\end{array}$

Source: Computation from field survey (2015)

Table 2.2 Computation of correlation table from statement 6 of the questionnaire administered.

$\begin{array}{llllll}\text { Options } & \text { Points (X) } & \begin{array}{l}\text { Mean } \\ \text { Responses } \\ (\mathrm{Y})\end{array} & \mathrm{XY} & \mathrm{X}^{2} & \mathrm{Y}^{2} \\ \mathrm{SA} & 5 & 22.5 & 112.5 & 25 & 506.25 \\ \mathrm{~A} & 4 & 7.50 & 30 & 16 & 56.25 \\ \mathrm{~N} & 3 & 1.50 & 4.5 & 9 & 2.25 \\ \mathrm{D} & 2 & 9.00 & 18 & 4 & 81 \\ \mathrm{SD} & 1 & 24.50 & 24.5 & 1 & 600.25 \\ \sum & 15 & 65 & 189.5 & 55 & 1246\end{array}$

Source: Author's Computation (2015) 
$\mathrm{r}=\underline{\mathrm{n}(\Sigma \mathrm{xy})-\left(\sum \mathrm{x}\right)\left(\sum \mathrm{y}\right)}$

$\sqrt{n}_{\mathrm{n}\left[\Sigma \mathrm{x}^{2}-(\Sigma \mathrm{x})^{2}\right]\left[\mathrm{n} \Sigma \mathrm{y}^{2}-(\Sigma \mathrm{y})^{2}\right.}$

Where: $\mathrm{n}=5 ; \sum \mathrm{x}=15 ; \sum \mathrm{y}=65 ; \sum \mathrm{xy}=189.5 ; \sum \mathrm{x}^{2 ;}=55 ; \sum \mathrm{y}^{2}=1246 \mathrm{r}=-0.09$

Decision: The calculated $r$ of - 0.09 indicates a strong negative relationship and therefore the Null hypothesis is accepted which means that there is no relationship between the self-regulation policy of the auditing profession and deficient standard setting.

Table 3 Computation of correlation from statement 3 of the questionnaire:

The establishment of Independent Oversight Board will have no effect on AEG in Nigeria

Auditors and the Regulators Users of Financial Statements

Options Points Responses $\begin{array}{llllllllll}\mathrm{Xy} & \mathrm{X}^{2} & \mathrm{Y}^{2} & \text { Points } & \text { Responses } & \mathrm{Xy} & \mathrm{X}^{2} & \mathrm{Y}^{2}\end{array}$
(x) (y)
(x) (y)

$\begin{array}{lllllllllll}\text { SA } & 5 & 14 & 70 & 25 & 196 & 5 & 36 & 180 & 25 & 1296 \\ \mathrm{~A} & 4 & 15 & 60 & 16 & 225 & 4 & 13 & 52 & 16 & 169 \\ \mathrm{~N} & 3 & 4 & 12 & 9 & 16 & 3 & 1 & 3 & 9 & 1 \\ \mathrm{D} & 2 & 19 & 38 & 4 & 361 & 2 & 4 & 8 & 4 & 16 \\ \mathrm{SD} & 1 & 18 & 18 & 1 & 324 & 1 & 6 & 6 & 1 & 36 \\ \sum & 15 & 70 & 198 & 55 & 1122 & 15 & 60 & 249 & 55 & 1520\end{array}$

Source: Author's computation from field survey (2015) 


\section{Macrothink \\ International Journal of Accounting and Financial Reporting \\ ISSN 2162-3082 2015, Vol. 5, No. 2}

Table 3.1 Computation of Correlation Table from Statement 3 of the administered questionnaire

$\begin{array}{llllll}\text { Options } & (\mathrm{X}) & \text { mean }(\mathrm{Y}) & \mathrm{XY} & \mathrm{X}^{2} & \mathrm{Y}^{2} \\ & \text { Points } & \text { Responses } & & & \\ \mathrm{SA} & 5 & 25 & 125 & 25 & 625 \\ \mathrm{~A} & 4 & 14 & 56 & 16 & 196 \\ \mathrm{~N} & 3 & 2.5 & 7.5 & 9 & 6.25 \\ \mathrm{D} & 2 & 11.5 & 23 & 4 & 132.25 \\ \mathrm{SD} & 1 & 12 & 12 & 1 & 144 \\ \sum & 15 & 65 & 223.50 & 55 & 1103.50\end{array}$

Source: Author's Computation from field survey result

Pearson's coefficient of correlation ( $\mathrm{r}$ ) can be worked out using the following model and results from field survey:

$\mathrm{r}=\underline{\mathrm{n}(\Sigma \mathrm{xy})-\left(\sum \mathrm{x}\right)(\Sigma \mathrm{y})}$

$\sqrt{n}_{\mathrm{n}\left[\Sigma \mathrm{x}^{2}-(\Sigma \mathrm{x})^{2}\right]\left[\mathrm{n} \Sigma \mathrm{y}^{2}-(\Sigma \mathrm{y})^{2}\right.}$

Where $\mathrm{n}=5 \sum \mathrm{x}=15 ; \sum \mathrm{y}=65 ; \sum \mathrm{xy}=223.50 ; \sum \mathrm{x}^{2}=55 ; \sum \mathrm{y}^{2}=1103.50 ; \sum(\mathrm{y})^{2}=4225$

$$
r=\underline{5(223.50)-(15)(65)}
$$

$\sqrt{ }\left[5(55)-(15)^{2} \quad 5(1103.50)-(65)^{2}\right]$

$=1117.5-975=142.5$

$50 \times 1292.5=\sqrt{64625}$

$\mathrm{r}=0.5610$

Decision: The calculated $r$ of 0.56 indicates a fairly strong positive relationship and therefore the Null hypothesis is rejected which means that the establishment of transparently independent oversight body has a significant positive relationship on audit expectation gap in Nigeria. 


\section{Discussion of Result and conclusion}

The identified significant relationships of 0.60 and 0.56 in hypothesis I and 3 are consistent with field result in table 1 and findings in many previous studies. For example, After an empirical study by Salehi, Mansoury and Azary (2009) it was deduced that one of the major factors that fuel the AEG is the profession's self-regulatory policy which permits it to set standards for itself, determines what auditor's role and responsibilities should be and carried out management advisory services for audit client and still remain "independent". Also iIn 2010, an exploratory study with 30 participants by Ismail, Mustapha and Ali was undertaken in Malaysia and it was found that although the auditing profession in Malaysia has International Auditing Standards as prescribed minimum level of quality in the delivery of audit assurance services, self regulation by the profession alone appears inadequate to ensure delivery of quality audit services (Ismail, Mustapha and Ali, 2010). Lee, Ali and Gloeck (2009) in a similar study asserted that the reason for an audit expectation gap is due to the contradiction between minimal government regulation of the profession, and the profession's right to self-regulation, particularly, the problem of the profession's overprotection of self-interest. Olowokere (2010) stated that the refusal of auditors to assume responsibility for fraud detection and reporting exercise; and their involvement with non-audit services and self-regulation policy appear to have extended the audit expectations gap. The positive relationship of $56 \%$ is also in tandem with the result of a similar study in USA by Islam in 2013 where it was observed that in order to restore the market confidence within auditing profession and to raise the overall audit quality, countries across the USA, the United Kingdom (UK), Europe, and Asia-Pacific are establishing super regulatory bodies to oversee the functions of auditing and auditors (Islam, 2013). The strong negative relationship of -0.09 resulting from hypothesis 2 indicates that deficient standard gap may not necessarily be a direct effect of self-regulation. This is because, some certain parts of our legal pronouncement like the Nigeria companies Act. 1990 are obsolete and need to be revamped since they have direct effect in the standard process. This also means that public education is important on the standard setting process. This recommendation is in line with the findings of other academic researchers. For example, Ihendinihu and Robert (2014), Pierce and Kilcommins (1996) Haniffa and Hudaib (2007),

This finding has far reaching implications for the auditing/accountancy profession, educational institutions, regulators, and the general public. The profession is invited to note that reasonable and achievable but unmet expectations of the public cannot be eliminated through audit education alone. Such expectations may arise from sub-standard performance of the auditor or from deficient set of regulation which are not covered by existing audit regulations and our legal pronouncements. The profession may re-examine existing auditing standards with a view to accommodating reasonable expectations of the public which were not adequately covered in existing regulations to avoid the temptation of promoting the acceptance of deficient set of auditing standards.

Finally, a close monitoring of members in audit practice by transparently independent oversight body may help in checking unethical and unprofessional practices within the profession in order to reduce expectation gap. 


\section{Macrothink}

International Journal of Accounting and Financial Reporting ISSN 2162-3082 2015, Vol. 5, No. 2

\section{References}

AAA (1973)' A Statement on Basic Auditing Concepts, Saratosa Florida

Adams, C.A. and Evans, R (2002) 'Factors Influencing Corporate Social and Ethical Reporting Moving on from Extant Theories', Accounting, Auditing and Accountability Journal 15.2:223-50

Adams, C.A. and Evans, R (2004) Accountability, Completeness, Credibility and the Audit Expectation Gap; Journal of Completeness and Credibility; Summer 2004. Deakin University ,Australia. Vol. 14, pp. 97-115.

Akinbuli, S.F. (2010), 'The Effect of Audit Expectation Gap on the Work of Auditors, the Profession and Users of Financial Information; The Nigerian Accountant, Vol.43.No.4; pp.37-47

Alleyne, P. \& Howard, M. (2005), 'An Exploratory Study of Auditor' Responsibility for Fraud Detection in Barbados’ .Managerial Auditing Journal, Vol.17 no.8, pp. 478-489.

Anderson, B., Maletta M. \& Wright, A. (1998), „Perceptions of auditor responsibility: Views of the judiciary and the profession", International Journal of Auditing, Vol. 2, No. 3, pp. 215-232. bias effects and the expectation gap. Journal of Economic Psychology 14: 711-737.

Alreck PL, Settle, R. B. (1995). The Survey Research Handbook. (2nd ed.). Chicago: Richard D. Irwin Inc.

Baridam, D.M. (2008),' Research Method in Accounting and Finance, $3^{\text {rd }}$ Edition:

Sharbrooke Associates, Port Harcourt .

Brady, N. (1992) Beholding the sunset for the gray men in grey suits. The Accountants, January 1992, pp.14-15

Braun, V and Clarke, V (2006) Using thematic analysis in psychology, Qualitative research in psychology, vol. 3 (2) pp. 77-101

Canadian Institute of Chartered Accountants (CICA), (1998), 'Report of the Commission on the Study of Public Expectation of Audit', Toronto.

Cosserat, G. W., \& Rodda, N. (2009) Modern Auditing $3^{\text {rd }}$ edition, John Wiley \& Sons.

Denscombe, M. (2003), 'The Good Research Guide for Small-scale Social Research Project'. $2^{\text {nd }}$ Edition, Maidenhead-Philadelphia, Open University Press

Dixson, R., Woodhead, A.D. \& soliman, M. (2006), 'An Investigation of Expectation Gap in Egypt' Managerial Auditing Journal, Vol.2, no.3, pp. 293-302.

Fadzly, M.N. \& Ahmad, Z. (2004), 'The Perceived Value of the Financial Statement Audit' Proceeding of International Conference on Quality Financial Reporting and Corporate Governance; Kaula, Lumpur, Malaysia.

Flint, D.(1998), 'Philosophy and Principles of Auditing'. An Introduction. Macmillan London. 


\section{MInstitute Macrothink $_{\text {Int }}$}

International Journal of Accounting and Financial Reporting ISSN 2162-3082

Gold, A. Gronewold, U. and Pott, C. (2012) 'The ISA 700 Auditor's Report and the Audit Expectation Gap - Do Explanations Matter'? VU University, Amsterdam, anna.gold@ vu.nl

Haniffa, R. \&Hudaib, M. (2007), 'Locating Audit Expectations gap within a cultural context. the case of Saudi Arabia, Journal of Accounting, Auditing and Taxation Vol.16, no.2,pp.1-28.

Holmes, A.W. \& Burn, D.C.(2009), Auditing standards and procedures, $9^{\text {th }}$ Edition ,Richards D . Irwin Inc.

Humphrey, C.G., Moizer, P. \& Turley, W.S. (1993), 'The Audit Expectation Gap in Britain: An Empirical Investigation', Accounting and Business Research, Vol. 23,pp.395-411.

Humphrey, C, (1997), 'Debating Audit Expectations in Sherer. M.\& Turley, S. Current ICAN (2014) Institute of Chartered Accountants of Nigeria, official Journal, Vol.....no. Issues In Auditing, $3^{\text {rd }}$ Edition, London. Paul Publishing Ltd.

Islam ,M.(2013)Auditing in the 21st Century: Has Self-regulation Failed? Journal of Modern

Accounting and Auditing, ISSN 1548-6583 August 2013, Vol. 9, No. 8, 1059-1069

Ismail, H., Mustapha, M. \& Mat Ali, N. (2013)" Regulation of Audit Quality: Auditors Expectations of the Audit Oversight Board"2nd International Conference on Management, Economics and Finance (2nd icmef 2013) Proceeding

Ihendinihu, J.U. \& Robert, S.N. (2014), 'Role of Audit Education in Minimizing Audit Expectation Gap in Nigeria'. International Journal of Business andManagement; Vol.9, no.2; pp.20311.

Keeley, T., Al-Janabi, H Lorgelly, P., \& Coast, J. (2013). A qualitative assessment of the content validity of the ICECAP-A and EQ-5D-5L and their appropriateness for use in health research: e85287. PLoS One, 8(12), 1-8.

Knapp, M. C. (2011). Contemporary auditing: Real issues \& cases (9th ed.). Oklahoma, OH: South-Western.

Lahey W. (2007) Self-Regulation and Unification Discussions in Canada's Accounting Profession; A Framework for Uniting the Canadian Accounting Profession, online:

http://cpacanada.cala-frameworkfor-uniting-the-canadian-accounting-profession/.

Lee, T.H., Ali, A. Md., \&Gloeck, J.D. (2009), The Audit Expectation Gap in Malaysia: An Investigation Into its Causes and Remedies. South African Journal of Accountability andAuditing Research, Vol.9: pp. 57-88.

Lennox, C. (2009), 'The changing regulatory landscape: editorial: International journal of Auditing, Vol.13, no.2; 79-85.

Liggio, C. (1974), The Expectation Gap: the Accountant's Waterloo. Journal of Contemporary Business, Vol.3. pp. 27-44

Lin, Z.J. \& Chen, F. (2004), „An empirical study of the audit "expectation gap" in the People ${ }^{e e}$ Republic of Chinae, International Journal of Auditing, Vol. 8, pp. 93-115. 


\section{MInstitute ${ }_{\text {Mnk }}^{\text {Macrothin }}$}

International Journal of Accounting and Financial Reporting ISSN 2162-3082

McEnroe, J.E. \& Martens, S.C. (2001), Auditors and Investors Perceptions of the expectation Gap'. Accounting Horizon, Vol. 15 no.4, pp.345-358.

Monroe, G, \&Woodliff, D.R, (1994), An Empirical Investigation of the Audit Expectation Gap: Australia Evidence. Accounting and Finance Journal, Vol. 34, no.1, pp. 47-75

Oakshott L., (2006) Essential Quantitative Methods for Business Management and Finance, $3^{\text {rd }}$ Edition; Palgrave Macmillan, Hampshire New York.

Ogunbameru, O. A. (2003). Research Methods in Social Science (2nd Ed.) Norway: D-Net

Communication E-Books Press.

Ojo, M. (2006) 'Eliminating the Audit Expectation Gap: Myth or Reality? MPRA Online at http:/mpra.ub.uni-muenchen.de/232/MPRA Paper No.232; accesses 10/08/15.

Olowokere, J.K. (2011) 'Stakeholders Perception of Audit Performance Gap in Nigeria'. International Journal of Accounting and Finance, Vol.1, no. 1, pp. 152-172.

Oseni, A.I., \&Ehimi, C.O. (2010), 'Existence and Nature of Audit Expectation Gap:Nigerian Perspective'.Asian Economic and Financial Review Vol.2.No.8.pp.1051-1063.

Pierce, B., \& Kilcommins, M. (1996). The Audit Expectation Gap: The Role of Auditing Education. Dublin City University Business School Research Papers Series No. 13.

Porter, B. (1993), An Empirical Study of the Audit Expectation Performance Gap. Accounting And Business Research, Vol.24 no.93; pp.49-68

Porter, B. \&Gowthorpe, C. (2004), Audit Expectation Performance Gap in the UK In 1999 and Comparison with New Zealand in 1999.The Institute of Chartered Accountant of Scotland Edinburgh

Power, M. (1994), The Audit Explosion. Demos London.Power, M. (1998), Auditor's Liability in Context. Accounting, Organizations and Society.23(1), pp.77-79.

Porter, B., Simon, J. \& Hatherly, D. (2005) Principles of external auditing, John Wiley \& Sons, Ltd, West Sussex

Rodda, N. (2001) 'Audit and Internal Review; Foulk Lynch Ltl. Middlessex; pp. 7.

Rehana, F. (2010). An Empirical Study on Audit Expectation Gap: Role of Auditing Education In Bangladesh

Salehi, M.M., (2007), 'Reasonableness of Audit Expectation Gap: Possible Approach to Reducing The Gap'. International Journal of Audit Practice. Vol. 3 pp.50-59.

Sikka, P., Puxty,T., Willmoutt, H. \& Cooper, C. (1998), The Impossibility of Eliminating Audit Expectation Gap: Some Theory and Evidence. Critical Perspectives on Accounting.Vol.9,pp. 229-330.

Swamy, M., ( 2007), An Empirical Study of Corporate Audit Expectation Gap inBangalore City. Unpublished PhD Thesis, University of Mysore. India

Witten, M. (1990) ‘Guardians on Guard, CA Magazine, Nov., 1990’ pp.26-30. 


\section{Macrothink}

International Journal of Accounting and Financial Reporting

ISSN 2162-3082 2015, Vol. 5, No. 2

Wolf, F., Trackett, J. \& Claypool, G. (1999), Audit Disaster Futures: Antidotes for the Expectation Gap?'.Managerial Auditing Journal, 14(9); 468-478.

\section{Copyright Disclaimer}

Copyright reserved by the author(s).

This article is an open-access article distributed under the terms and conditions of the Creative Commons Attribution license (http://creativecommons.org/licenses/by/3.0/). 